REDIMAT

Journal of Research in Mathematics Education
Hipatia Press

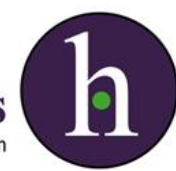

Instructions for authors, subscriptions and further details:

http://redimat.hipatiapress.com

\title{
List of Reviewers
}

Date of publication: February $24^{\text {th }}, 2017$

Edition period: February 2017-June 2017

To cite this list of reviewers: (2016). List of Reviewers. REDIMAT, 6(1), 115. doi: 10.17583/redimat.2017.2586

To link this article: http://dx.doi.org/10.17583/redimat.2017.2586

\section{PLEASE SCROLL DOWN FOR ARTICLE}

The terms and conditions of use are related to the Open Journal System and to Creative Commons Attribution License (CC-BY). 
REDIMAT, Vol. 6 No. 1 February $24^{\text {th }} 2017$ pp. 115

\section{List of Reviewers}

On behalf of REDIMAT we deeply appreciate contributions provided by the reviewers to the quality of this journal, during 2016. The journal owes this debt with those who have been peer reviewers during this period. Yours sincerely,

Javier Díez-Palomar

Berta Barquero

Editors

Adriana Aubert

Aitor Gómez

Ana Corica

Andreas Moutsios-Rentzos

Benedetto di Paola

Berta Barquero

Eugenia Vomvoridi-Ivanovic

Francisco Javier García

Jair Aguilar

Joan Cabré

Linda Ahl

Maria Brisola Brito

Maura McLeman

Olga Serradell

Patricia Melgar
Paulo Alfonso

Peter Appelbaum

Pilar Álvarez

Silvia Molina

Vicenç Font 